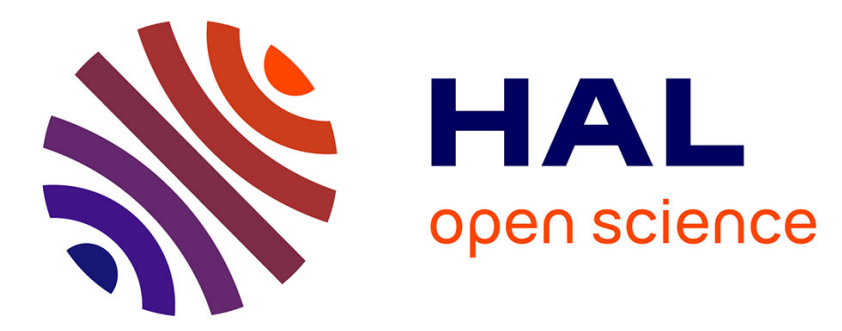

\title{
Changes in thermal conductivity, suction and microstructure of a compacted lime-treated silty soil during curing
}

Yejiao Wang, Yu-Jun Cui, Anh Minh A.M. Tang, Chaosheng Tang, Nadia

Benahmed

\section{To cite this version:}

Yejiao Wang, Yu-Jun Cui, Anh Minh A.M. Tang, Chaosheng Tang, Nadia Benahmed. Changes in thermal conductivity, suction and microstructure of a compacted lime-treated silty soil during curing. Engineering Geology, 2016, 202, pp.114-121. 10.1016/j.enggeo.2016.01.008 . hal-01514384

\author{
HAL Id: hal-01514384 \\ https://hal.science/hal-01514384
}

Submitted on 3 May 2017

HAL is a multi-disciplinary open access archive for the deposit and dissemination of scientific research documents, whether they are published or not. The documents may come from teaching and research institutions in France or abroad, or from public or private research centers.
L'archive ouverte pluridisciplinaire HAL, est destinée au dépôt et à la diffusion de documents scientifiques de niveau recherche, publiés ou non, émanant des établissements d'enseignement et de recherche français ou étrangers, des laboratoires publics ou privés. 
1 Changes in thermal conductivity, suction and microstructure of a

\section{2 compacted lime-treated silty soil during curing}

3

4 Yejiao WANG ${ }^{1}$, Yujun $\mathrm{CUI}^{1}$, Anh Minh $\mathrm{TANG}^{1}$, Chaosheng $\mathrm{TANG}^{2}$, Nadia BENAHMED ${ }^{3}$

$6{ }^{1}$ : Ecole des Ponts ParisTech, U.R. Navier/CERMES, 6 - 8 av. Blaise Pascal, Cité Descartes,

7 Champs - sur - Marne, 77455 Marne - la - Vallée cedex 2, France

$8 \quad$ 2: School of Earth Sciences and Engineering, Nanjing University, 163 Xianlin Road, Nanjing 9210093 , China

103 : IRSTEA, Groupe de Recherche "Ouvrages hydrauliques", 3275 route Cézanne, CS 40061, 1113182 Aix En Provence Cedex 5

Corresponding author:

E-mail: yu-jun.cui@enpc.fr 


\section{Abstract}

An experimental study was conducted to investigate changes of thermal conductivity, suction and microstructure of a lime-treated silty soil during curing. The soil samples were prepared with $2 \%$ lime and compacted dry (17\%) and wet (22\%) of optimum. The thermal conductivity, total suction and pore size distribution were determined at various curing times. Results show that the thermal conductivity of samples compacted on the dry side decreases slightly with curing time, while the curing time effect on the samples compacted on the wet side is insignificant. The total suction generally increases with curing time even though the soil water content was kept constant. The pore size distribution characteristics are mainly related to its moulding water content. As the samples are compacted on the dry side, the pore size distribution shows typical bi-modal characteristics, with a population of macro-pores and a population of micro-pores. By contrast, as the samples are compacted on the wet side, the pore size distribution shows typical uni-modal characteristics. It is found that the modal size of both the large and small pores decreases with curing time.

Keywords: thermal conductivity; suction; microstructure; lime-treated soil; curing time; mercury intrusion porosimetry. 
Lime treatment is widely applied in geo-engineering constructions such as highway and railway embankments, levees and slopes. This technique effectively improves the workability and mechanical behaviour of soils, because lime can significantly modify soil properties through a series of physical-chemical reactions, including hydration, cation exchanges and pozzolanic reaction (Bell, 1996; Boardman et al. 2001; Prunsinski and Bhattacharja, 1999; Umesha et al. 2009). Generally, lime hydration takes place shortly after adding lime into the soil, and this process consumes a large amount of water. The main products of this first step reaction is $\mathrm{Ca}(\mathrm{OH})_{2}$. The followed ionization of hydration products provides sufficient $\mathrm{Ca}^{2+}$ ions, and induces cation exchanges that lead to soil flocculation/agglomeration. Note that the cation exchanges and the consequent flocculation process occur rapidly after lime addition, resulting in changes in aggregate size distribution, plasticity and workability of soil (Bell, 1989; Russo, 2005). Pozzolanic reaction usually takes a longer time and plays the major role in improving soil geotechnical behaviour, by increasing soil stiffness and shear strength (Bell, 1996; Consoli et al. 2009; Tang et al. 2011; Dong, 2013). Due to the time-dependence of lime-soil reactions, the geotechnical behaviour of lime-treated soil depends significantly on curing time (Locat et al. 1990; Bell, 1996; Little, 1999; AL-Mukhtar et al. 2012; DI Sante et al. 2014). Brandl (1981) and Liu et al. (2012) reported that the strength of lime-treated soil increased with increasing curing time. By performing bender element tests on lime-treated soils, Dong (2013) showed that there was a two-stage development for the shear modulus over time: stage 1 related to cation exchanges and stage 2 to pozzolanic reaction.

In most cases, lime-treated soils are exposed to natural environment or placed in shallow 
depth. They are unavoidably subjected to long-term cyclic climate loadings, i.e. temperature variations, drying and wetting, which can significantly affect their durability. Recent studies mainly focus on the effect of wetting and drying cycles on the mechanical behaviour of lime-treated soil (Khattab et al. 2007; Cuisinier and Deneele, 2008; Le Runigo, 2008; Tang et al. 2011), and little attention has been paid to the effect of temperature, which is also an important factor related to climate. Actually, temperature can also significantly affect the geotechnical properties of soil, such as Atterberg limits, stiffness, strength and volume change behaviour (Ctori, 1989; De Bruyn and Thimus, 1996; Sultan et al. 2002; Liu et al. 2012; Islam et al. 2013; Consoli et al. 2014). To assess the temperature effect, it appears essential to investigate soil thermal properties like thermal conductivity. Indeed, thermal conductivity is an important parameter in the modelling of the coupled thermo-hydro-mechanical behaviour of lime-treated soil under climate changes. It takes an important role in the heat transformation between the soil and the atmospheric air. However, most studies on thermal behaviour of treated soil involved cement stabilization in the past decades. Farouki (1981) reported that the addition of Portland cement into sand increased the thermal conductivity of the mixture in both wet and dry states. Adam and Jones (1995) observed that the thermal conductivity of cement stabilized soil was higher than that of lime-stabilized soil, and they explained that the former enhanced soil density while the later reduced it. Nevertheless, El-Rawi and Al-Wash (1995) indicated that the thermal conductivities of both soil-cement mixture and concrete decreased with curing time. Lee et al. (2014) tested the mixtures of the gold tailings and fly ash, showing a decrease of thermal conductivity of the mixtures with curing time. From these studies, it appears that the changes in thermal conductivity of 
lime-treated soil and especially the effect of curing time have not been well understood yet.

Due to the climate effect, field lime-treated soils are usually at unsaturated state. Thus, suction is a basic parameter to describe the state of soil-water-air system. For lime-treated soils, it was found that the cation exchanges and the induced flocculation can modify the water retention capacity of soil. Russo (2005), Tedesco and Russo (2008) observed an increase in water retention capacity by lime addition. Russo (2005), Cecconi and Russo (2008) attributed this phenomenon to the reduced interconnection between pores. Khattab et al. (2002) compared the water retention curve of a lime-treated clay with that of untreated one, and showed that the small increase of suction for the treated clay was due to water consumption by lime hydration. In longer term, pozzolanic reaction becomes dominant in lime-treated soils, creating cementitious compounds and giving rise to the modification of both microstructure and water retention capacity of soil.

To better understand the observed macroscopic behaviour of soil such as thermal conductivity, water retention capacity and stiffness, it is often required to perform soil microstructure investigation. Mercury intrusion porosimetry (MIP) is one of the most widely used techniques for this purpose. For lime-treated soils, due to the time-dependence of lime-soil interactions, their microstructure is time-dependent. Russo et al. (2007) performed MIP tests on lime-treated silt cured at different times, and highlighted the time-dependency of microstructure changes: the cation exchanges and pozzolanic reaction reduced the porosity and increased the quantity of small pores. Khattab et al. (2007) also studied the microstructure changes of a lime-treated expansive soil under wetting/drying cycles, and found that the total pore volume of treated soil increased drastically with wetting/drying cycles. 
The above-mentioned studies show that different soil properties have been investigated for different cement/lime-treated soils, and there is no study on different soil properties with a fixed soil and a fixed treatment. This appears however essential to well understand different mechanisms involved in the treatment processes. In this study, the changes of thermal conductivity, suction and microstructure of a lime-treated unsaturated silty soil were analysed during curing time. Two groups of soil samples were prepared at dry and wet sides of optimum. The thermal conductivity, water retention capacity and pore size distribution of the samples at various curing times (from 1 to 90 days) were determined. Results allowed the coupled thermo-hydro-mechanical behaviour and the microstructure characteristics to be analysed.

\section{MATERIALS AND METHODS}

\section{Test materials}

The soil tested was taken from a site near Héricourt, France. This soil has a fine fraction $(<80$ $\mu \mathrm{m})$ of $65 \%$. Its geotechnical properties are reported in Table 1. According to French/European standard NF P 11-300 (1992), this soil belongs to category A2. It corresponds to a silt of high plasticity (MH) following the Unified Soil Classification System (USCS). The main minerals are quartz (55\%), kaolinite (12\%), feldspaths (11\%), illite (10\%), goethite (6.5\%), montmorillonite (4\%), chlorite (1\%) and rutile $(0.5 \%)$ (Deneele \& Lemaire, 2012). In Figure 1, both grain size distribution of natural soil and aggregate size distribution of soil powder used in this study are presented. The grain size distribution was obtained on the natural soil by the wet sieving method (NF P 94-056, for particles larger than $80 \mu \mathrm{m}$, and by the hydrometer method (NF P 94-057, for particles smaller than $80 \mu \mathrm{m}$ ). Natural soil was 
first air-dried, ground and then passed through the target sieve of $0.4 \mathrm{~mm}\left(D_{\max }\right)$. The larger soil aggregates which could not pass through this sieve were ground again, until all soil passed through (Tang et al. 2011). Then the "aggregate size distribution" was determined by dry sieving method.

Quicklime was used as additive. It is the same lime used in the embankment construction at Héricourt, France. The main properties of this lime are presented in Table 2. In accordance with the lime treatment in the embankment construction at Héricourt, $2 \%$ lime by dry weight of soil was chosen as the lime dosage.

\section{Sample preparation}

After the soil powder was prepared $\left(D_{\max }=0.4 \mathrm{~mm}\right), 2 \%$ quicklime powder was first mixed with dry soil. Then the soil-lime mixture was humidified by distilled water to reach different target water contents. According to the compaction curves of lime-treated soil determined from standard Proctor test (NF P 94-093, 1999) in Figure 2 (where the curve of untreated soil is also shown), both the dry side $\left(w_{d r y}=17 \%\right)$ and the wet side of optimum water content $\left(w_{\text {wet }}=22 \%\right)$ with the same dry density $\left(\rho_{d}=1.65 \mathrm{Mg} / \mathrm{m}^{3}\right)$ were considered. The water contents and dry density were chosen according to the values applied in the field for the embankment construction in Héricourt, France. After a mellowing period of 1 hour, static compaction by 3 layers was performed to reconstitute the samples at the target dry density and different sizes to satisfy the requirements of different tests. For instance, the samples for thermal conductivity test had $50 \mathrm{~mm}$ in diameter and $75 \mathrm{~mm}$ in height; the samples for suction measurement had $38 \mathrm{~mm}$ in diameter and $100 \mathrm{~mm}$ in height; the samples for MIP test had 50 $\mathrm{mm}$ in diameter and $20 \mathrm{~mm}$ in height. Immediately after compaction, sample was carefully 
covered by plastic membrane and wrapped in a film. Then the sample was enveloped by scotch tape, confined in a hermetic box and cured in a chamber at a relative humidity of $100 \%$ and a temperature of $20 \pm 2^{\circ} \mathrm{C}$.

\section{Thermal conductivity tests}

A thermal properties analyzer, KD2 (Decagon Devices Inc.) was used to measure the thermal conductivity of samples. Its principle is based on the transient hot-wire method. The thermal probe is a single-needle (KS-1) with a size of $1.3 \mathrm{~mm}$ diameter and $60 \mathrm{~mm}$ length. Its accuracy is $5 \%$ and the measurement range is $0.02-2 \mathrm{~W} / \mathrm{mK}$. This device meets the requirements of ASTM Standards (ASTM D5334-00, 2000). In order to install the thermal probe into the soil, a hole of $1.3 \mathrm{~mm}$ diameter and $60 \mathrm{~mm}$ depth was drilled in the centre of each compacted sample. As shown in Figure 3, a layer of thermal grease was first applied on the surface of the probe to ensure a good contact between the soil and the probe. Then, the thermal probe was installed inside of the soil sample. Before starting the measurement, about 10 min was needed for the temperature inside of the sample reaching stability. After that, the measurement was started by pressing the key "Enter" on the device. It took about $1-2 \mathrm{~min}$ for one measurement. Note that the measurement was performed in the laboratory at a temperature of $20 \pm 2^{\circ} \mathrm{C}$. This measurement was being conducted during the whole curing time of $t=90$ days for each soil sample.

\section{Suction measurement}

Once the samples were compacted, they were covered in watertight plastic films and stored for $24 \mathrm{~h}$ for water homogenization. Then the samples were cut into 6 or 8 small pieces (38 
$\mathrm{mm}$ in diameter and $8 \mathrm{~mm}$ in height) which were well covered to prevent water evaporation during curing time. At a given curing time, one small piece was put into the dew point PotentiaMeter (WP4) to measure its suction. Immediately after the suction measurement, the water content was determined by oven-drying.

The dew point PotentiaMeter (WP4) measures the total suction in a sample. The total suction $(\psi)$ of the sample was determined through Kelvin's equation:

$$
\psi=\frac{R T}{M} \ln R H
$$

where $R$ is the gas constant $(8.31 \mathrm{~J} / \mathrm{mol} \mathrm{K}), T$ is the Kelvin temperature of the sample, $M$ is the molecular mass of water, $R H$ is the relative humidity.

As $R H$ is dependent on temperature (Tang and Cui, 2005), it is important to measure the temperature for each $R H$ measurement. In the dew point PotentiaMeter, the dew point temperature of air is measured by a dew point sensor and the sample temperature is measured by an infrared thermometer.

\section{Microstructure investigation}

For the MIP tests, one small piece (around $1.1 \mathrm{~g}$ of dry soil) was cut carefully from the compacted sample (50 mm in diameter and $20 \mathrm{~mm}$ in height) at a certain curing time $(\mathrm{t}=1$, 28 and 90 days). Each small piece was freeze-dried immediately following the procedure proposed by Delage and Pellerin (1984), and then subjected to MIP test. Autopore IV 9500 mercury intrusion porosimeter which has both low-pressure and high-pressure systems was used. The pressure started from a value of 3 to $4 \mathrm{kPa}$ in the low- pressure part up to around $230 \mathrm{MPa}$ in the high-pressure part. With increasing pressure, mercury gradually intruded into 
the sample starting from a maximum entry diameter of $355 \mu \mathrm{m}$ to a minimum value of 0.006 $\mu \mathrm{m}$ according to Laplace's law:

$$
p=\sigma \cos \theta\left(\frac{1}{r_{1}}+\frac{1}{r_{2}}\right)
$$

where $r_{1}$ and $r_{2}$ are the curvature radii - in the case of spherical interface, $r_{1}=r_{2} ; \sigma$ is the surface tension (taken equal to $0.485 \mathrm{~N} / \mathrm{m}$ ); $\theta$ is the contact angle (taken equal to $130^{\circ}$ ); $p$ is the applied pressure.

Since the mercury cumulative intrusion can be assimilated to the air intrusion process, the following equation can be deduced:

$$
d=-\frac{4 \sigma_{m} \cos \theta_{m}}{p_{m}}=\frac{4 \sigma_{w} \cos \theta_{w}}{p_{w}}
$$

where $d$ is the diameter of intruded pore (assumed to be cylindrical), $\sigma$ is the surface tension, $\theta$ is the contact angle, $p$ is the intrusion pressure, subscript $m$ denotes mercury while subscript $w$ denotes water. In this study, the following values were taken: $\sigma_{m}=0.485 \mathrm{~N} / \mathrm{m}, \sigma_{w}=0.073$ $\mathrm{N} / \mathrm{m}, \theta_{m}=130^{\circ}$ and $\theta_{w}=0^{\circ}$.

The relationship between matric suction $\left(u_{a}-u_{w}\right)$ and mercury intrusion pressure $p_{m}$ can be deduced from Eq. (3):

$$
\left(u_{a}-u_{w}\right)=-\frac{\sigma_{w} \cos \theta_{w}}{\sigma_{m} \cos \theta_{m}} p_{m}
$$

The water content $w$ and degree of saturation $S_{r}$ can be determined using the following equations by considering the residual water content $w_{r}$ (Romero, 1999):

$$
w=\left(1-S_{r m}\right)\left(w_{s a t}-w_{r}\right)+w_{r}
$$




$$
S_{r}=\left(1-S_{r m}\right)+\frac{w_{r}}{w_{s a t}} S_{r m}
$$

where $S_{r m}$ is the degree of saturation of mercury, $w_{\text {sat }}$ is the water content at saturation.

\section{EXPERIMENTAL RESULTS}

\section{Thermal conductivity tests}

Figure 4 shows the thermal conductivity of lime-treated samples versus curing time on a semi-logarithmic scale. It can be seen that, for the samples compacted on the wet side, the curing effect on the thermal conductivity is negligible, the value remaining around 1.50 $\mathrm{W} / \mathrm{mK}$. For the samples compacted on the dry side, the thermal conductivity decreases slightly during curing. At $t=1$ day, the thermal conductivity is about $1.36 \mathrm{~W} / \mathrm{mK}$; it decreases by $5.1 \%$ to about $1.29 \mathrm{~W} / \mathrm{mK}$ at $t=90$ days. The decreasing thermal conductivity with curing time was also reported for soil-cement mixture and concrete (El-Rawi and Al-Wash, 1995), gold tailings and fly ash mixtures (Lee et al. 2014), cement paste (Hansen et al, 1982). Mojumdar et al. (2006) measured the thermal conductivity of synthetic calcium silicate hydrate $(\mathrm{C}-\mathrm{S}-\mathrm{H})$, the main cementitious product of lime treatment, and a value of 0.1012 $\mathrm{W} / \mathrm{mK}$ at $25^{\circ} \mathrm{C}$ was found. Note that the value for water is $0.6 \mathrm{~W} / \mathrm{mK}$, much higher than that of C-S-H (Van Wijk, 1963; Farouki, 1981). This explains why wet samples $(w=22 \%)$ always have higher thermal conductivity than the dry samples $(w=17 \%)$.

\section{Suction measurement}

The suction variations with curing time are shown in Figure 5a. As expected, at given curing 
time, the suction of dry side samples $(\mathrm{w}=17 \%)$ is generally higher than that of wet side samples $(\mathrm{w}=22 \%)$. It is also observed that the suction of all samples increases with curing time. For the samples compacted dry of optimum, the suction is $270 \mathrm{kPa}$ at $\mathrm{t}=2$ days; then it gradually increases to $500 \mathrm{kPa}$ at $\mathrm{t}=90$ days. Similarly, for the samples compacted wet of optimum, the suction increases from $170 \mathrm{kPa}$ at $\mathrm{t}=4$ days to $300 \mathrm{kPa}$ at $\mathrm{t}=90$ days. Interestingly, these suction changes occur in almost constant water content conditions. Indeed, Figure $5 \mathrm{~b}$ shows that the measured water contents remain almost constant with curing time: the water content of the wet side samples is about $22 \%$, and that of dry samples is about $17 \%$ during the whole curing time. Note that the dry density was monitored during curing and a variation of $0.119-0.850 \%$ was recorded. This variation is very small and its effect on suction changes can be ignored. It can be deduced that the lime treatment increases the water retention capacity of soils. This is consistent with the observations made by Russo (2005), Cecconi and Russo (2008), and Tedesco (2007), suggesting that the water retention capacity of lime-treated soils is improved over time.

\section{Microstructure investigation}

The derived curves and the corresponding cumulative curves are presented in Figure 6 for the samples compacted on dry side, and in Figure 7 for the samples compacted on wet side. It is observed that the derived curves of the samples compacted on dry side (Figure 6a) show typical bi-modal characteristics, indicating the presence of two populations of pores: macro-pores and micro-pores, while the samples compacted on the wet side illustrate typical uni-modal characteristics, indicating the presence of only one population of pores (Figure 7a). These observations are in agreement with those of Delage et al. (1996) on compacted silt and 
Russo et al. (2007) on lime-treated silt. In Figure 6a, each curve corresponds to a curing time $(t=1,28$, and 90 days). It appears that the average entry diameters of both macro-pores and micro-pores slightly decrease with curing time. Specifically, the size of macro-pores decreases from $5.27 \mu \mathrm{m}$ to $4.18 \mu \mathrm{m}$ after 90 day curing; for the population of micro-pores, its modal size also decreases from $0.23 \mu \mathrm{m}$ to $0.07 \mu \mathrm{m}$ after 90 curing days. Similar results are obtained on the samples compacted on wet side. The single peak of pores shifts from $0.28 \mu \mathrm{m}$ at 1 day to $0.13 \mu \mathrm{m}$ at 90 days (Figure $7 \mathrm{a}$ ).

The cumulative curves are plotted in a semi-logarithmic scale, in terms of mercury intruded void ratio as a function of entrance pore diameter as indicated in Figure $6 \mathrm{~b}$ and Figure $7 \mathrm{~b}$. With curing time, the final intrusion void ratio of the samples compacted on the wet side continues to decrease and does not stabilize (Figure 7b); this decrease is more obvious for the samples compacted on dry side (Figure 6b).

According to the pore size distribution curves shown in Figure 6a and Figure 7a, the water retention curves can be determined as explained in section Materials and Methods, and they are presented in Figure 8. Note that the suction determined from MIP curve corresponds to capillary suction or matric suction. The corresponding measured total suction values are also presented for comparison. On the dry side, at $\mathrm{w}=17 \%$ (Figure $8 \mathrm{a}$ ), the matric suction obtained from the curves increases from about 400 to about $1000 \mathrm{kPa}$ when the curing time increases from 1 to 90 days. Similarly, on the wet side, at $\mathrm{w}=22 \%$ (Figure $8 \mathrm{~b}$ ), the matric suction also increases from about 180 to $300 \mathrm{kPa}$ when the curing time increases from 1 to 90 days. In comparison with the direct measurements, the matric suction seems to be higher than the total suction - the direct measurement points are located beneath the curves from the MIP 
tests. This seems to be weird and will be discussed in the following section. On the whole, both the direct and indirect measurement data illustrate that the water retention capacity of lime-treated samples is improved gradually with curing time. This is in good agreement with the results of Russo (2005), Cecconi and Russo (2008), and Tedesco (2007).

\section{DISCUSSION}

Soil effective thermal conductivity is significantly controlled by the volumetric components.

Generally, soil consists of solid particles which contain various minerals with different thermal properties. They are surrounded by pore-air and pore-water. It was reported that the thermal conductivity of most soil minerals is around $2.7 \mathrm{~W} / \mathrm{mK}$ (Farouki, 1981). However, the thermal conductivity value of the main hydration product (C-S-H) of lime is 0.1012 W/mK, much lower than that of water (0.6 W/mK) (Mojumdar et al. 2006; Farouki, 1981). Thus, the presence of pozzolanic products during curing decreases the effective thermal conductivity of the whole system.

Soil thermal conductivity also significantly depends on soil structure defined by soil porosity, pore size distribution, particle contacts, etc. In general, soil compacted at different water contents presents different microstructures (Delage et al. 1996). As shown in Figure 6 and Figure 7, the soil compacted dry of optimum (degree of saturation of about 67\%) presents aggregated structure with large macro-pores, which are usually filled with continuous air phase and discontinuous water phase in case of low degree of saturation, most water being in the small pores inside the aggregates. By contrast, the soil compacted wet of optimum (degree of saturation of about $87 \%$ ) presents a dispersed structure with continuous water phase in the pores and air phase in mostly occluded state (Delage et al. 1996; Wroth and Houlsby, 1985; 
Alonso et al. 1987; Tedesco, 2007). These two different microstructures result in different thermal contacts among soil grains. It is therefore reasonable that the thermal conductivity of lime-treated soil is largely dependent on its initial compaction water content as shown by the results in Figure 4. On the dry side, the thermal conductivity of samples is dominated by the solid contacts between aggregates. But because in this case the macro-pores are filled with continuous pore air and discontinuous pore water, the thermal conductivity is relatively lower.

The cementitious compounds mainly coat the surface of aggregates (Deneele et al., 2010), and therefore modify the thermal contact conditions. Due to the relative low thermal conductivity of cementitious compounds, the overall thermal conductivity of treated soil decreases with increasing amount of cementitious compounds. As a result, the measured thermal conductivity of dry side samples decreases with curing time (Figure 4). On the wet side, the dispersed structure has more solid contacts between soil particles than aggregated structure of dry side samples. Moreover, the liquid phase in pores is continuous and dominates the heat transfer process in soil. As indicated above, the thermal conductivity of water is about 6 times higher than cementitious compounds of lime. Consequently, the effect of cementitious compounds on the overall thermal conductivity of soil becomes negligible. This explains the observation in Figure 4 with the thermal conductivity of the wet side samples remaining almost unchanged during curing.

The suction determined by both direct and indirect measurements increases over curing time (Figure 8), while the water content dose not decrease (Figure 5). This is due to the fact that water consumption of lime mainly takes place in the first step of hydration and becomes negligible in the later pozzolanic reactions (Prusinski and Bhattacharja, 1999; Umesha et al. 
2009). The increase of suction can be attributed to the pozzolanic reaction which changes the soil microstructure. The results of MIP tests illustrate that the sizes of both macro-pores and micro-pores decrease continuously with curing time (Figure 6 and Figure 7). To some extent, the creation of cementitious compounds with a porous character would contribute to the increase in the quantity of micro-pores (Cerny et al. 2006; Deneele et al. 2010). Besides, the cementitious compounds are mainly coating on the surface of soil particles, blocking some entrances of micro-pores and increasing the occluded pores. Furthermore, cementitious products which occur at the clay edges, could bind the soil particles together, resulting in a reduction of macro-pore size and modifying the interconnection of macro-pores. All these changes would increase the water retention capacity of soil. As far as the difference of suction between the direct measurement and the indirect measurement is concerned, the water retention curves determined from MIP data correspond to the drying path, while the direct measurement points corresponds to a state between the drying path and the wetting path they are located in a scanning curve. It is thereby logical to have the direct measurement points below the curves from the MIP data (Figure 8).

\section{CONCLUSION}

A series of laboratory tests were performed on lime-treated silty soil samples compacted dry and wet of optimum. Emphasis was put on the effects of curing time on thermal conductivity, suction and microstructure. The obtained results allow the following conclusions to be drawn:

1) The samples compacted dry of optimum show typical bi-modal pore size distribution characteristics, while the samples compacted wet of optimum show typical uni-modal pore size distribution characteristics. With curing time, both the modal sizes of micro- 
pores and macro-pores shift to lower values, due to the cementitious compounds produced from pozzolanic reaction that fill the pores gradually over time.

2) The thermal conductivity of lime-treated soil over curing time significantly depends on

3) Due to the modification of microstructure by the generation of cementitious compounds, the suction of lime-treated soil generally increases with curing time, regardless of the moulding water content.

The obtained results give an insight into the modifications of soil properties induced by lime treatment during curing, helping better understand the curing effect on the evolutions of thermal conductivity, suction and microstructure of the lime treated soil. These results can be further used to analyse the thermo-hydro-mechanical behaviour of lime-treated soil. Moreover, this study also provides useful elements to appreciate the durability of lime-stabilised soils. It will be extended to other stabilised soils like lime-treated clay in order to verify the conclusions drawn. 


\section{ACKNOWLEDGEMENTS}

The authors wish to acknowledge the support of the European Commission via the Marie Curie IRSES project GREAT - Geotechnical and geological Responses to climate change: Exchanging Approaches and Technologies on a world-wide scale (FP7-PEOPLE-2013-IRSES- 612665). The support from China Scholarship Council (CSC) and Ecole des Ponts ParisTech are also gratefully acknowledged.

\section{REFERENCES}

Adams, E., Jones, P., 1995. Thermophysical properties of stabilised soil building blocks. Building and Environment 30 (2), 245-253

AL Mukhtar, M., Khattab, S., Alcover, J., 2012. Microstructure and geotechnical properties of lime-treated expansive clayey soil. Engineering Geology 139, 17-27.

Alonso E.E., Gens A., Hight D.W., 1987. Special problem soils-General report, IX ECSMFE. Dublin 3, 1087-1146.

ASTM D4373-02, 2007. Standard test method for rapid determination of carbonate content of soils. ASTM International, West Conshohocken, PA.

ASTM D5334-00, 2000. Standard test methods for determining of thermal conductivity of soil and soft rock by thermal needle probe procedure. ASTM International, West Conshohocken, PA. 
Bell, F. G., 1989. Lime stabilisation of clay soils. Bulletin of the International Association of Engineering Geology 39 (1), 67-74.

Bell, F. G., 1996. Lime stabilization of clay minerals and soils. Engineering Geology 42 (4), 223-237.

Boardman, D. I., Glendinning, S., Rogers, C. D. F., 2001. Development of stabilisation and solidification in lime-clay mixes. Géotechnique 51 (6), 533-543.

Brandl, H., 1981. Alteration of soil parameters by stabilization with lime. In Proceedings of the 10th International Conference on Soil Mechanics and Foundation Engineering. Vol.3, Stockholm.

Cecconi, M., Russo, G., 2008. Prediction of soil-water retention properties of a lime stabilised compacted silt. Unsaturated Soils: Advance in Geo-Engineering-Toll et al. (eds). Taylor \& Francis Group, London, ISBN 978-0-415-47692-8, 271-276.

Cerny, R., Kunca, A., Tydlitat, V., Drchalova, J., Rovnanikova. P., 2006. Effect of pozzolanic admixtures on mechanical, thermal and hygric properties of lime plasters. Construction and Building Materials 20(10), 849-857.

Consoli, N.C., Lopes, L.S., Heineck, K.S., 2009. Key parameters for the strength control of lime stabilized soils. Journal of materials in Civil Engineering 21 (5), 210-216.

Consoli, N.C., Gravina da Rocha, C., Silvani, C., 2014. Effect of Curing Temperature on the Strength of Sand. Coal Fly Ash, and Lime Blends, Journal of Materials in Civil Engineering $26(8), 06014015$.

Ctori, P., 1989. The effects of temperature on the physical properties of cohesive soil. Ground 
Engineering $22(5)$.

Cuisinier, O., Deneele, D., 2008. Impact of cyclic wetting and drying on the swelling properties of a lime-treated expansive clay. Jourées Nationales de Géotechnique et de Géologie de l'Ingénieur JNGG'08, Nantes, 18-20.

De Bruyn, D., Thimus, J., 1996. The influence of temperature on mechanical characteristics of Boom clay: the results of an initial laboratory programme. Engineering Geology 41 (1), $117-126$.

Delage, P., Audiguier, M., Cui, Y. J., Howat, M., 1996. Microstructure of a compacted silt. Canadian Geotechnical Journal 33 (1), 150-158.

Delage, P., Marcial, D., Cui, Y. J., Ruiz, X., 2006. Ageing effects in a compacted bentonite: a microstructure approach. Géotechnique 56 (5), 291-304.

Delage, P., Pellerin, F.M., 1984. Influence de la lyophilisation sur la structure d'une argile sensible du Québec. Clay Minerals 19 (2), 151-160.

Deneele, D., Cuisinier, O., Hallaire, V. Masrouri, F., 2010. Microstructural evolution and physico-chemical behavior of compacted clayey soil submitted to an alkaline plume. Journal of Rock Mechanics and Geotechnical Engineering 2(2), 169-177.

Deneele, D., Lemaire, K., 2012. Evaluation de la durabilité des sols - Effet de la circulation d'eau sur la durabilité du limon traité_Approche multi - échelle, Livrables du projet TerDOUEST (Terrassement Durables - Ouvrages En Sols Traités, 2008-2012).

DI Sante, M., Fratalocchi, E., Mazzieri, F., 2014. Time of reactions in a lime treated clayey soil and influence of curing conditions on its microstructure and behaviour. Applied Clay 
Science 99, 100-109.

Dong, J., 2013. Investigation of aggregates size effect on the stiffness of lime and/or cement treated soil: from laboratory to field conditions. PhD Dissertation, Ecole Nationale des Ponts et Chaussées, France.

EL Rawi, N., AL Wash, A., 1995. Strength and thermal properties of plain and reinforced soil-cement. Journal of Islamic Academy of Sciences 8 (3), 107-118.

Farouki, O., 1981. Thermal properties of soils. Cold Regions Research and Engineering Lab Hanover NH. Monograph, 81-1USA-CRREL.

Hansen, P.F., Hansen, J., Hougaard, K., Pedersen, E.J., 1982. Thermal properties of hardening cement paste. Proceedings of RILEM International Conference on Concrete at Early Ages. RILEM, Paris, 1982, 23-36.

Islam, S., Haque, A., Wilson, S.A., 2013. Effects of Curing Environment on the Strength and Mineralogy of Lime-GGBS-Treated Acid Sulphate Soils. Journal of Materials in Civil Engineering 26 (5), 1003-1008.

Khattab, S.A.A., AL-Mukhtar, M., Fleureau, J., 2002. Effect of initial suction on the swelling pressure and porosity of lime stabilized clays. Unsaturated Soils. Swets \& Zeitlinger, Lisse. ISBN 905809371 9, 605-609.

Khattab, S. A., Al-Mukhtzr, M., Fleureau, J. M., 2007. Long-term stability characteristics of a lime-treated plastic soil. Journal of Materials in Civil Engineering 19 (4), 358-366.

Lee, J., Shang, J., Jeong, S., 2014. Thermo-mechanical properties and microfabric of fly ash-stabilized gold tailings. Journal of Hazardous Materials 276, 323-331. 
Le Runigo, B., 2008. Duability of the lime-treated Jossigeny silt under different hydraulic stresses: assessment of the mechanical, hydraulic microstructural, microstructural behavior, PhD thesis, Ecole Centrale de Nantes et Universite de Nantes.

Little, D.N., 1999. Evaluation of structural properties of lime stabilized soils and aggregates. Vol.1: Summary of Findings Prepared for the National Lime Association.

Liu, M.D., Indraratna, B., Horpibulsuk, S., 2012. Variations in strength of lime-treated soft clays. Proceedings of the ICE-Ground Improvement 165 (4), 217-223.

Locat, J., Bérubé, M.A., Choquette, M., 1990. Laboratory investigations on the lime stabilization of sensitive clays: shear strength development. Canadian Geotechnical Journal 27 (3), 294-304.

Mojumdar, S., Raki, L., Mathis, N., Schimdt, K., Lang, S. 2006. Thermal, spectral and AFM studies of calcium silicate hydrate-polymer nanocomposite material. Journal of thermal analysis and calorimetry $85(1), 119-124$.

NF P 11-300, 1992. Standard for classification of materials for use in the construction of embankments and capping layers of road infrastructures.

NF P 94-051, 1988. Standard test for soils investigation and testing-Determination of Atterberg's limites-Liquid limit test using Casagrande appraratus-Plasitic limit test on rolled thread.

NF P 94-054, 1991. Standard test for soils investigation and testing-Determination of particle density-Pycnometer method.

NF P 94-068, 1998. Standard test for soils investigation and testing-Measurement of the 
methylene blue adsorption capacity of a rocky soil-Determination of the methylene blue of a soil by means of the stain test.

NF P 94-093, 1999. Stanard test for soils investigation and testing-Determination of the compaction characteristics of a soil-Standard Proctor test.

Prusinski, J. R., Bhattacharja, S., 1999. Effectiveness of Portland cement and lime in stabilizing clay soils. Transportation Research Record: Journal of the Transportation Research Board 1652 (1), 215-227.

Romero, E., 1999. Thermo-hydro-mechanical behaviour of unsaturated Boom clay: an experimental study. PhD Thesis, Universidad Politécnica de Catalunya, Barcelona, Spain.

Russo, G., 2005. Water retention curves of lime stabilised soil. Advanced Experimental Unsaturated Soil Mechanics. Taylor \& Francis, London, 391-396.

Russo, G., Dal Vecchio, S., Mascolo, G., 2007. Microstructure of a lime stabilised compacted silt. In Experimental Unsaturated Soil Mechanics, Springer Berlin Heidelberg, 49-56.

Sultan, N., Delage, P., Cui, Y., 2002. Temperature effects on the volume change behaviour of Boom clay. Engineering Geology 64 (2), 135-145.

Tang, A., Cui, Y., 2005. Controlling suction by the vapour equilibrium technique at different temperatures and its application in determining the water retention properties of MX80 clay. Canadian Geotechnical Journal 42 (1), 287-296.

Tang, A., Vu, M., Cui, Y., 2011. Effects of the maximum grain size and cyclic wetting/drying on the stiffness of a lime-treated clayey soil. Géotechnique 61, 421-429. 
487 Tedesco, D.V., 2007. Hydro-mechanical behaviour of lime-stabilised soils. PhD Thesis, 488 University of Cassino, Italy.

489 Tedesco, D., Russo, G., 2008. Time dependency of the water retention properties of a lime 490 stabilised compacted soil. Unsaturated Soils: Advance in Geo-Engineering-Toll et al. (eds). 491 Taylor \& Francis Group, London, ISBN 978-0-415-47692-8, 277-282.

492 Umesha, T., Dinesh, S., Sivapullaiah, P., 2009. Control of dispersivity of soil using lime and 493 cement. International Journal of Geology 3(1), 8-16.

494 Van Wijk, W., 1963. Physics of plant environment. Physics of Plant Environment.

495 Wroth C.P., Houlsby G.T., 1985. Soil mechanics: property characterization and analysis 496 procedure. Proc. of the XI ICSMFE, San Francisco (I), 1-55. 


\section{List of Tables}

Table 1 Geotechnical properties of the studied soil

Table 2 Parameters of the used lime

\section{List of Figures}

Figure 1 Aggregate size distribution of soil with Dmax $=0.4 \mathrm{~mm}$ and grain size distribution of natural soil

Figure 2 Normal proctor curve of lime-treated silt (after Dong, 2013)

Figure 3 Setup of thermal conductivity measurement: (a) sketch of setup; (b) photo of setup

Figure 4 Thermal conductivity of lime-treated soil during curing time

Figure 5 (a) Suction changes of lime-treated soil during curing time and (b) water content variations of lime-treated soil during curing time

Figure 6 (a) Derived pore size distribution curves of lime-treated samples compacted on the dry side and (b) cumulative curves of lime-treated sample compacted on the dry side (em: mercury intruded void ratio; d: entrance pore diameter and e: void ratio of the as-compacted sample)

Figure 7 (a) Derived pore size distribution curves of lime-treated sample compacted on the wet side and (b) cumulative curves of lime-treated sample compacted on the wet side

Figure 8 Water retention curves of lime-treated silt determined from MIP data: (a) at dry side; (b) at wet side 


\begin{tabular}{cc} 
Property & Value \\
\hline Specific gravity, $G_{s}(\mathrm{NF}$ P 94-054) & 2.70 \\
\hline Liquid limit, $w_{L}(\%)(\mathrm{NF}$ P 94-051) & 51 \\
\hline Plastic limit, $w_{p}(\%)(\mathrm{NF}$ P 94-051) & 28 \\
\hline Plasticity Index, $I_{p}(\%)(\mathrm{NF}$ P 94-051) & 23 \\
\hline VBS (g/100g) (NF P 94-068) & 2.19 \\
\hline CaCO ${ }_{3}$ content $(\%)(\mathrm{ASTM}$ D4373-02:2007) & 1.4 \\
\hline Optimum moisture content (\%) (NF P 94-093) & 1.76 \\
\hline Maximum dry unit mass (Mg/m $\left.{ }^{3}\right)(\mathrm{NF}$ P 94-093) & \\
\hline
\end{tabular}


Table 2 Parameters of the used lime

Chemical analysis

\begin{tabular}{cc}
\hline $\mathrm{CaO}(\%)$ & 97.30 \\
\hline $\mathrm{CaO}+\mathrm{MgO}(\%)$ & 98.26 \\
\hline $\mathrm{MgO}(\%)$ & 0.96 \\
\hline $\mathrm{CO}_{2}(\%)$ & 0.25 \\
\hline $\mathrm{SO}(\%)$ & 0.06 \\
\hline $\mathrm{Aggregate}$ size analysis \\
\hline$\leq 80 \mu \mathrm{m}(\%)$ & 82.7 \\
\hline$\leq 200 \mu \mathrm{mm}(\%)$ & 95.2 \\
\hline
\end{tabular}

528

529 
531 Figure 1 Aggregate size distribution of soil with $D_{\max }=\mathbf{0 . 4} \mathbf{~ m m}$ and grain size distribution of natural soil 532 


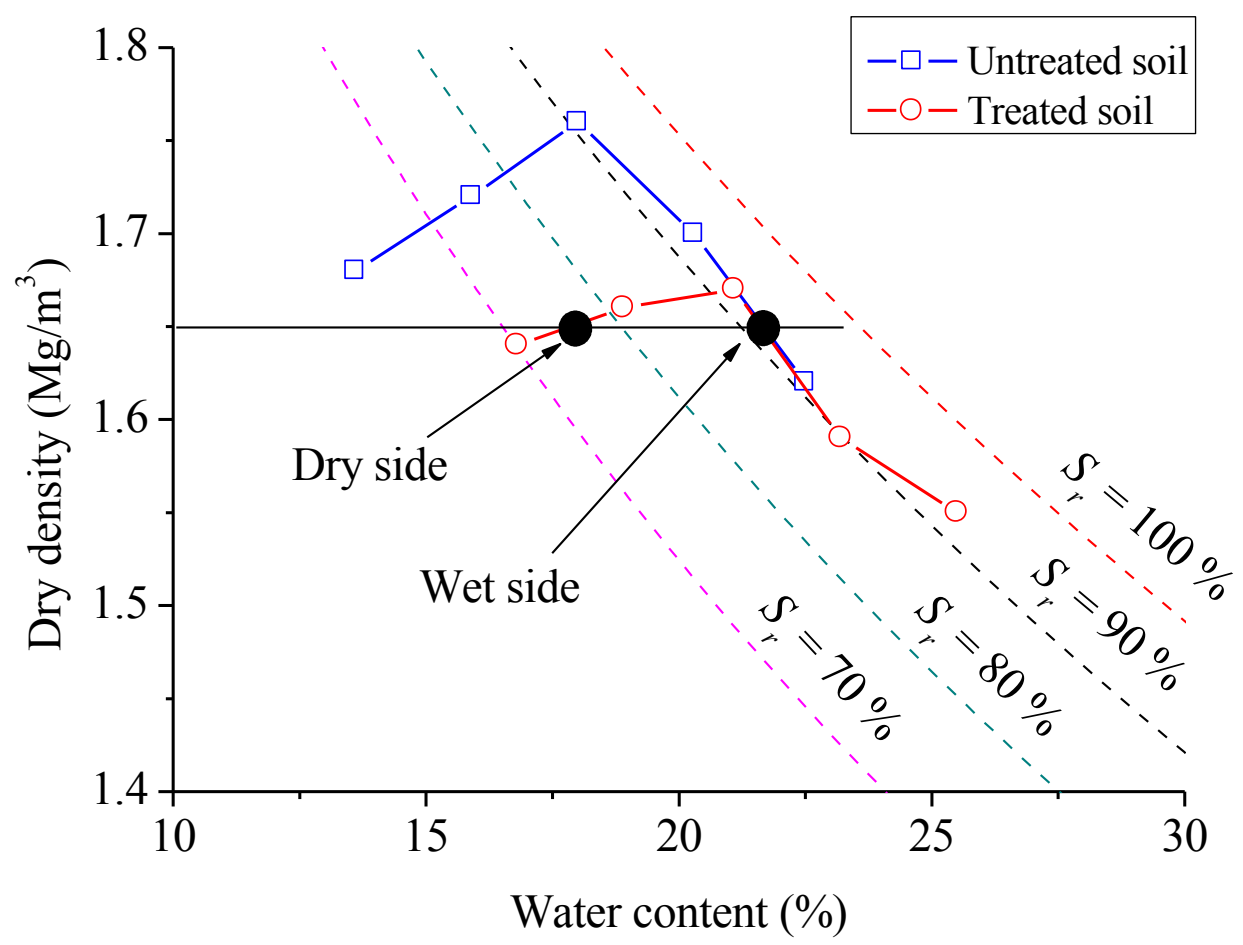

533

Figure 2 Normal proctor curve of lime-treated silt (after Dong, 2013) 
(a)

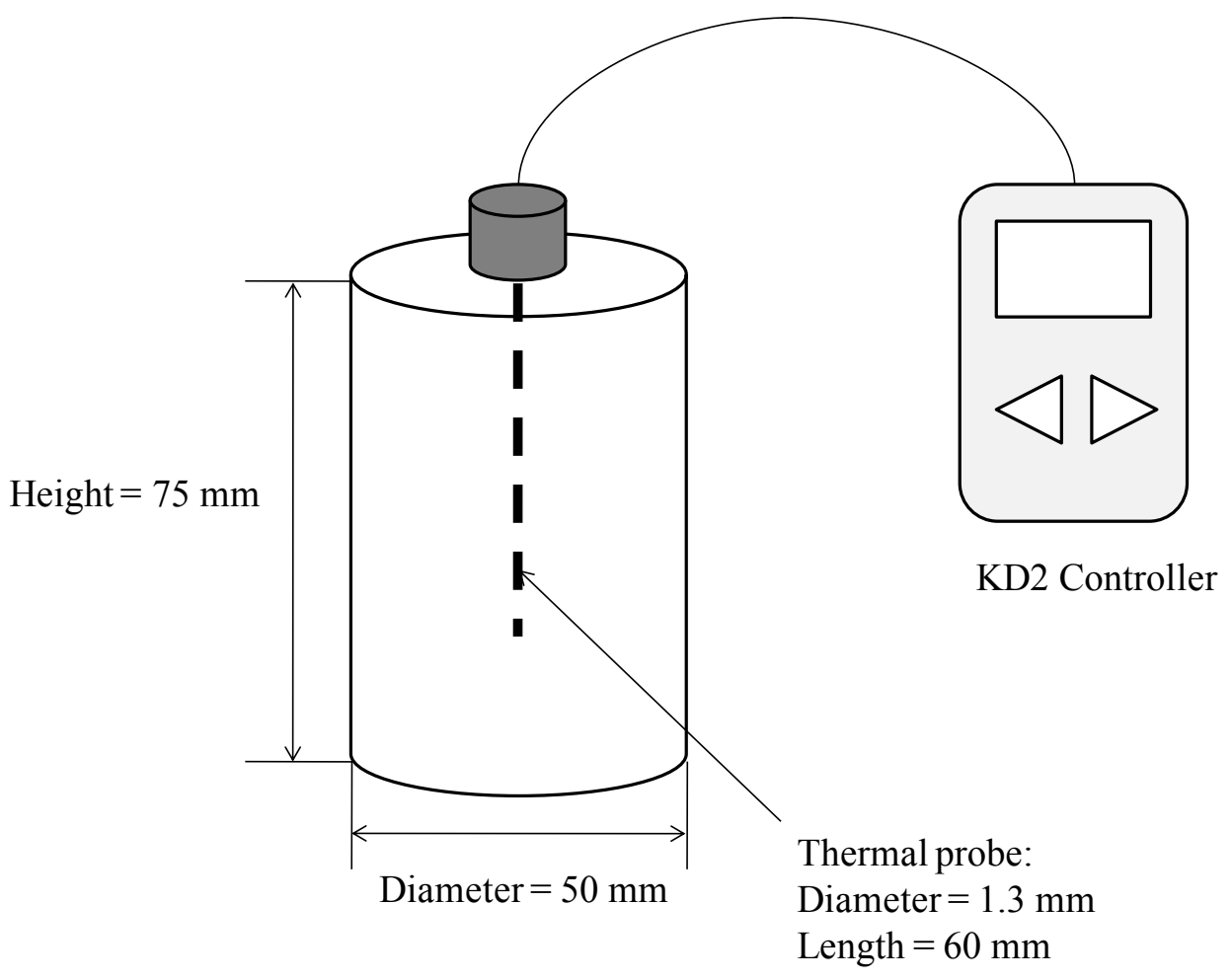

(b)

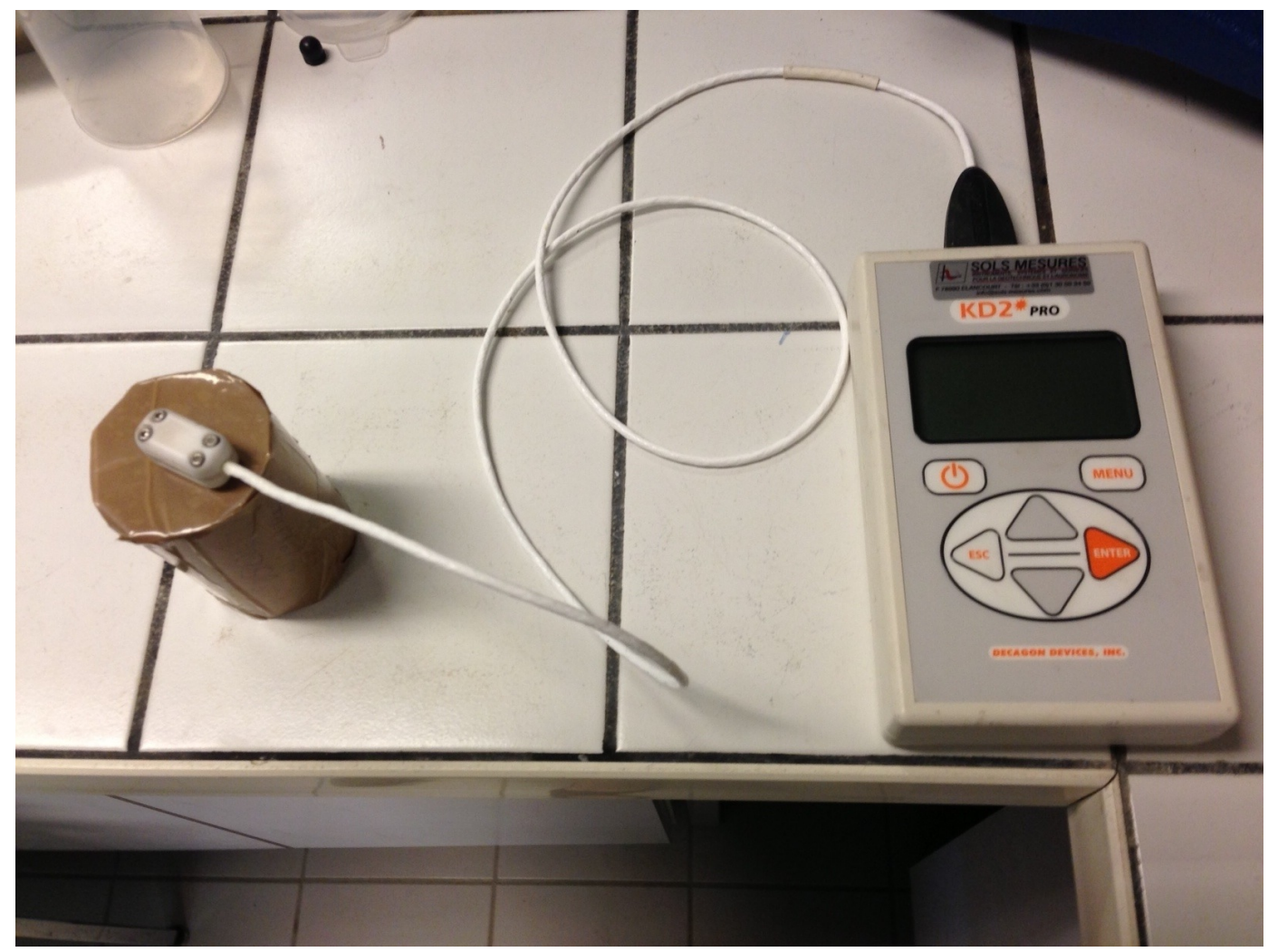

Figure 3 Setup of thermal conductivity measurement: (a) sketch of setup; (b) photo of setup 


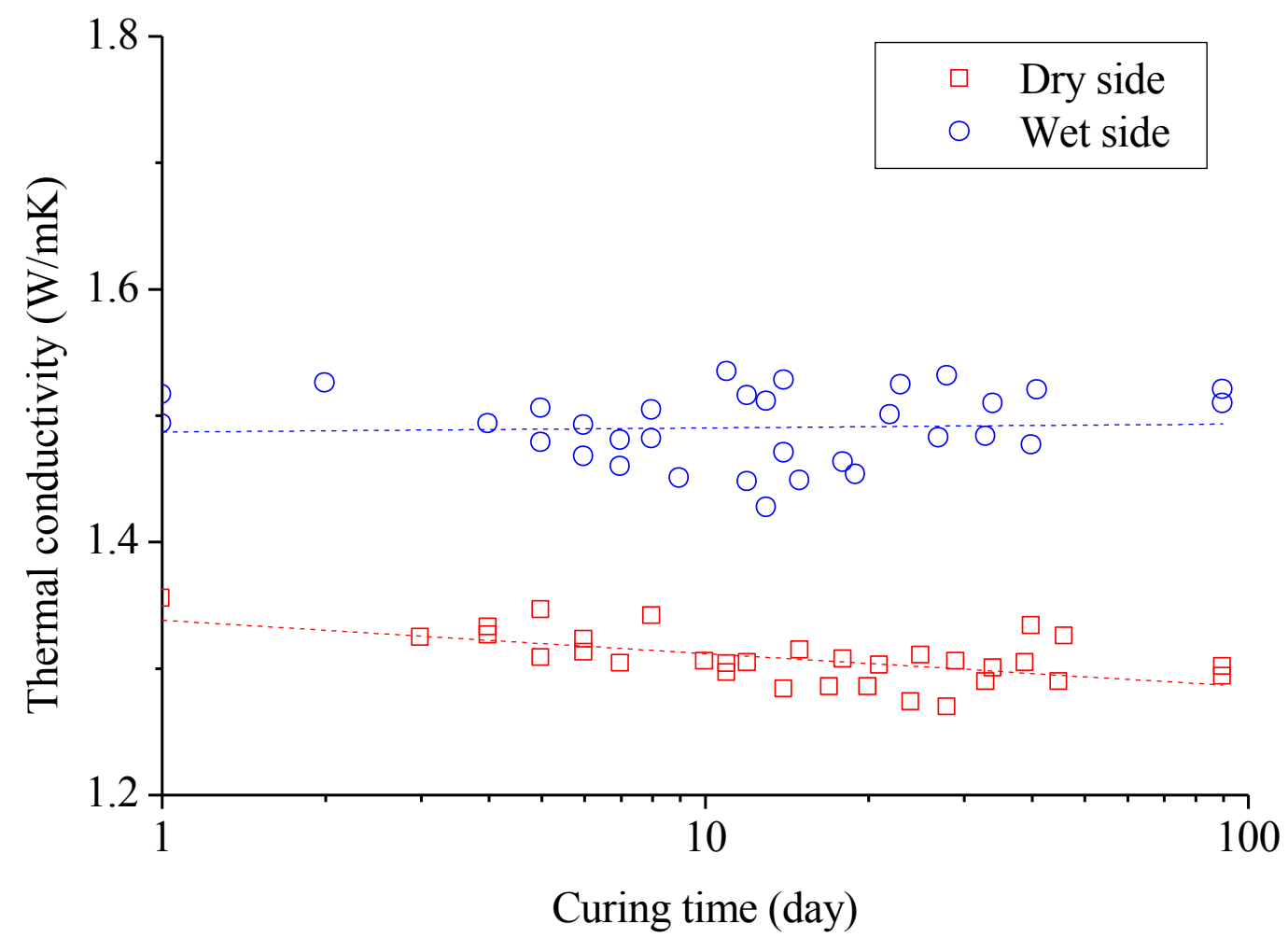


a)

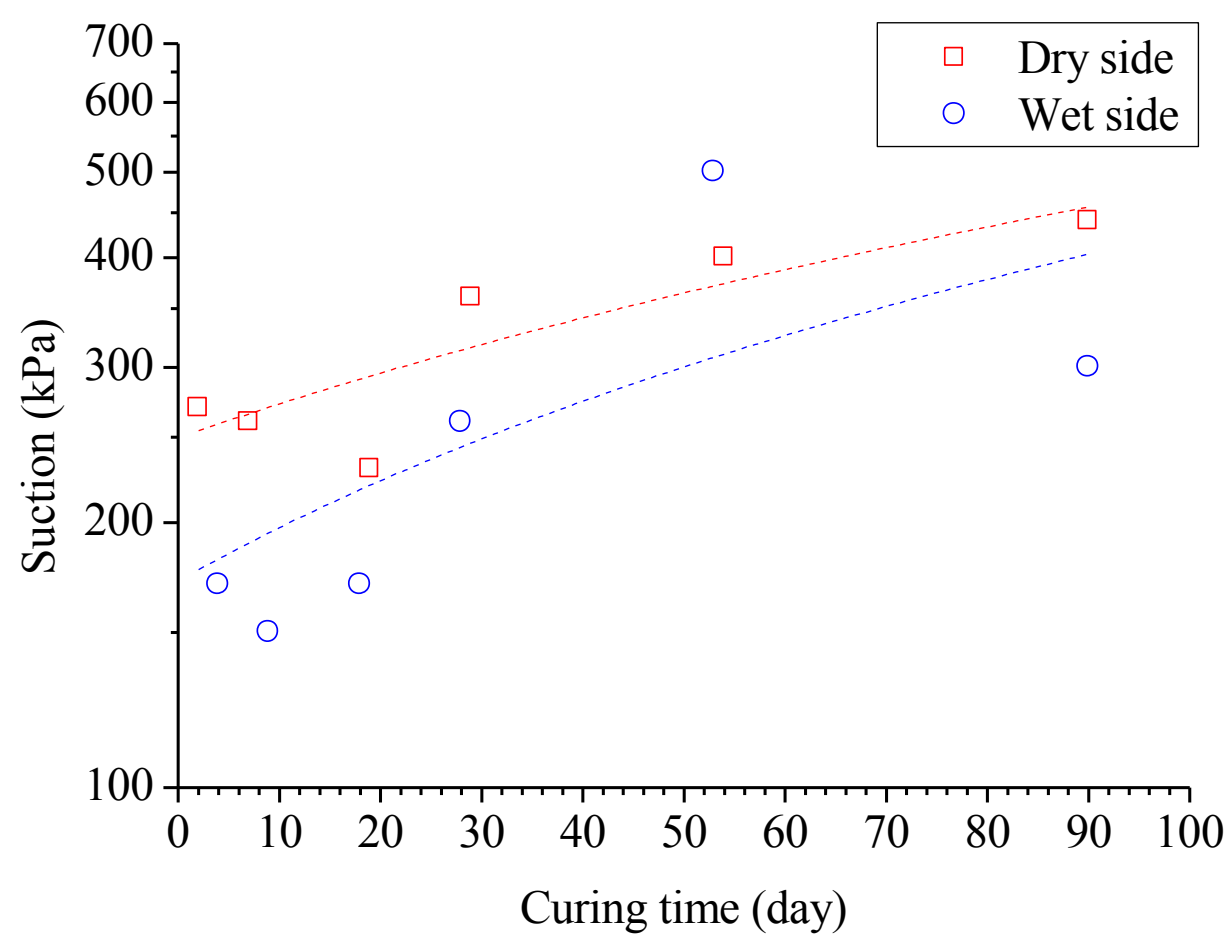

b)

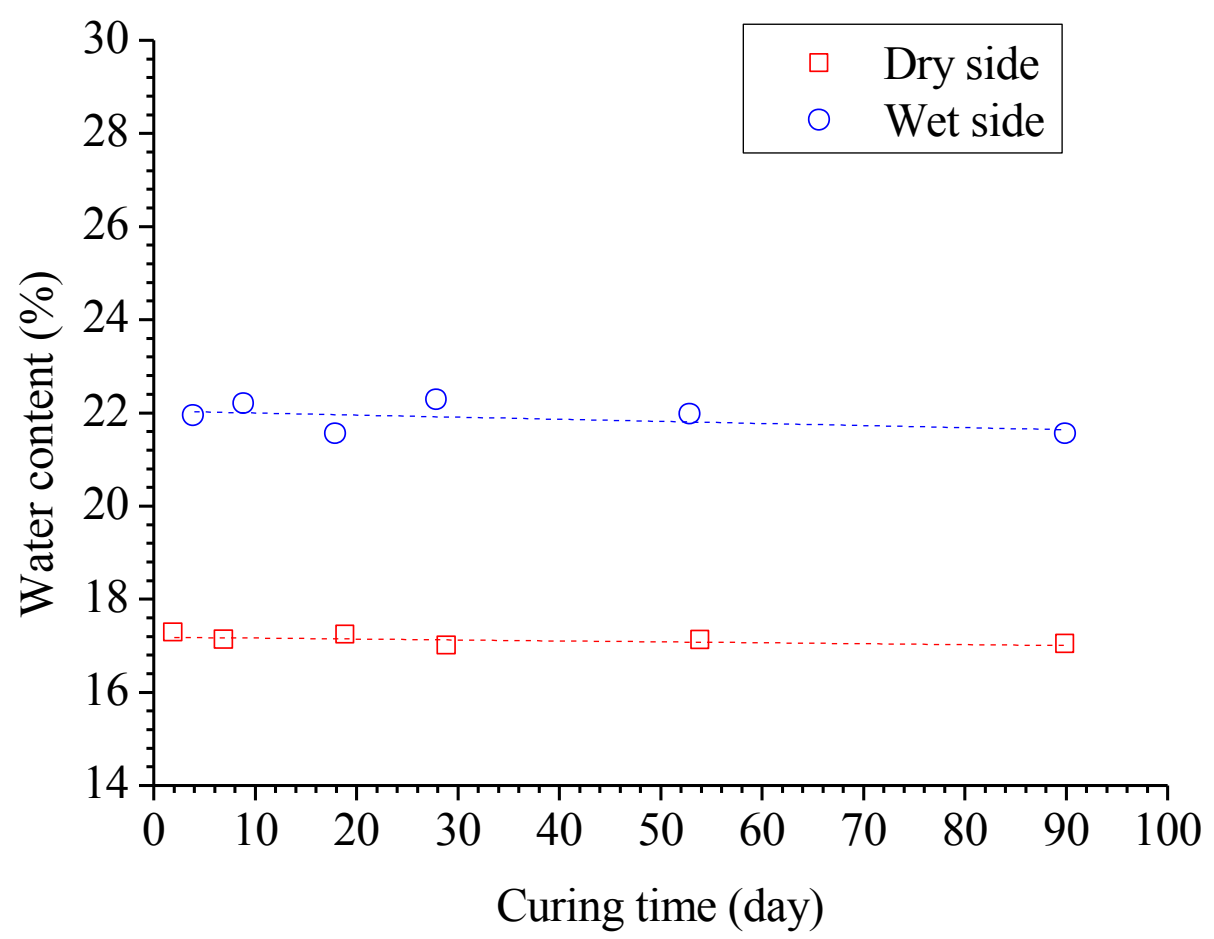

548 Figure 5 (a) Suction changes of lime-treated soil during curing time and (b) water content variations of 549 lime-treated soil during curing time 
a)

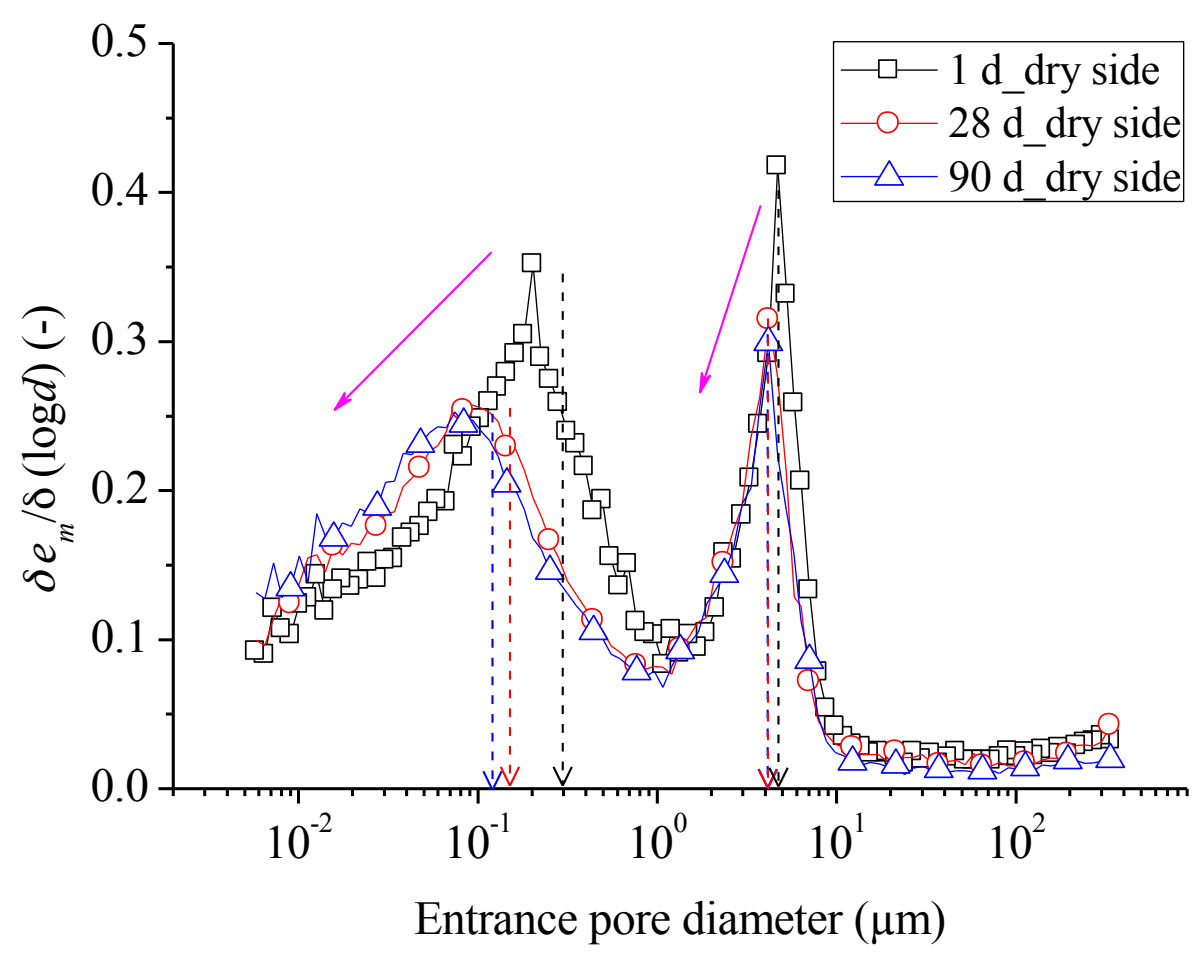

b)

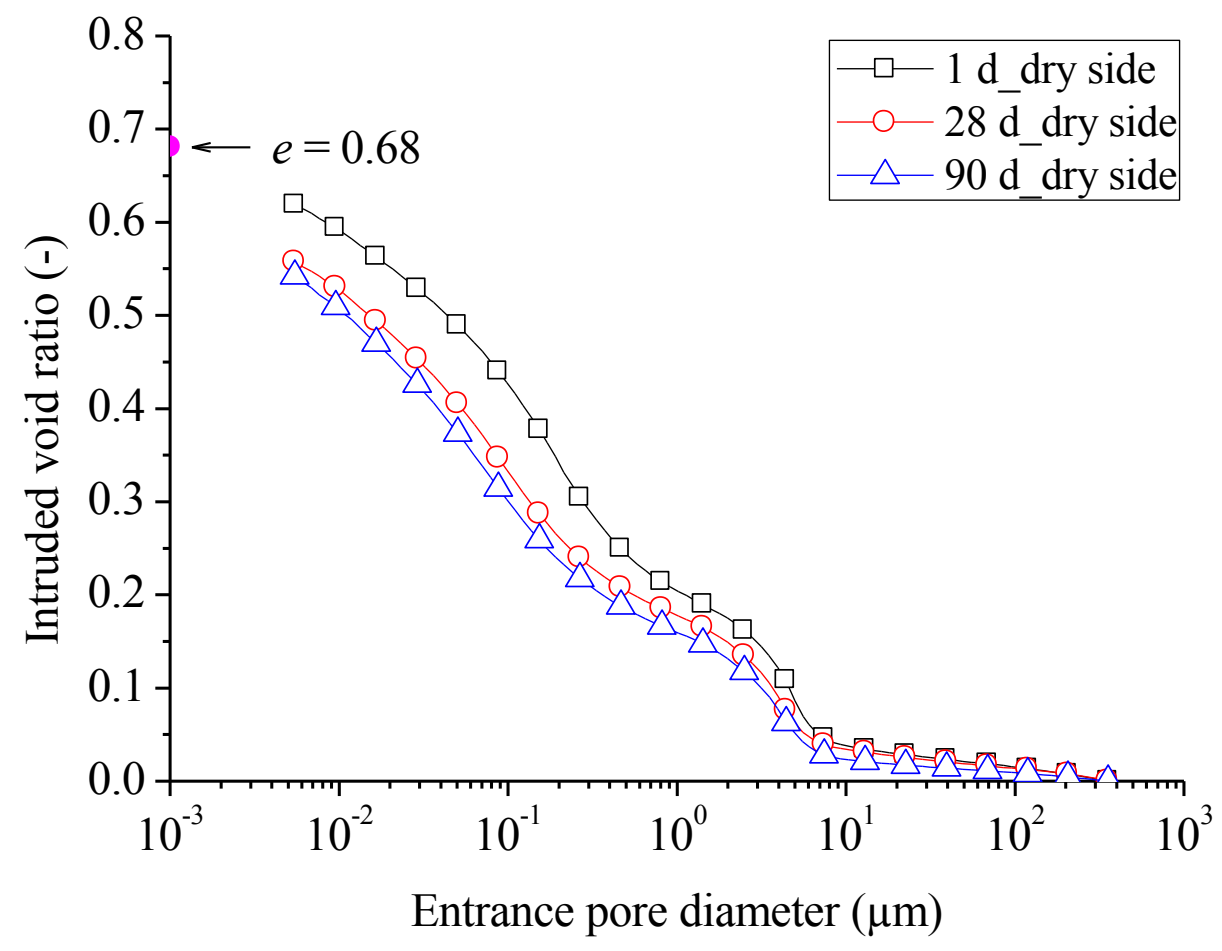

Figure 6 (a) Derived pore size distribution curves of lime-treated samples compacted on the dry side and (b) cumulative curves of lime-treated sample compacted on the dry side $\left(e_{m}\right.$ : mercury intruded void ratio; $d$ : entrance pore diameter and $e$ : void ratio of the as-compacted sample) 
a)

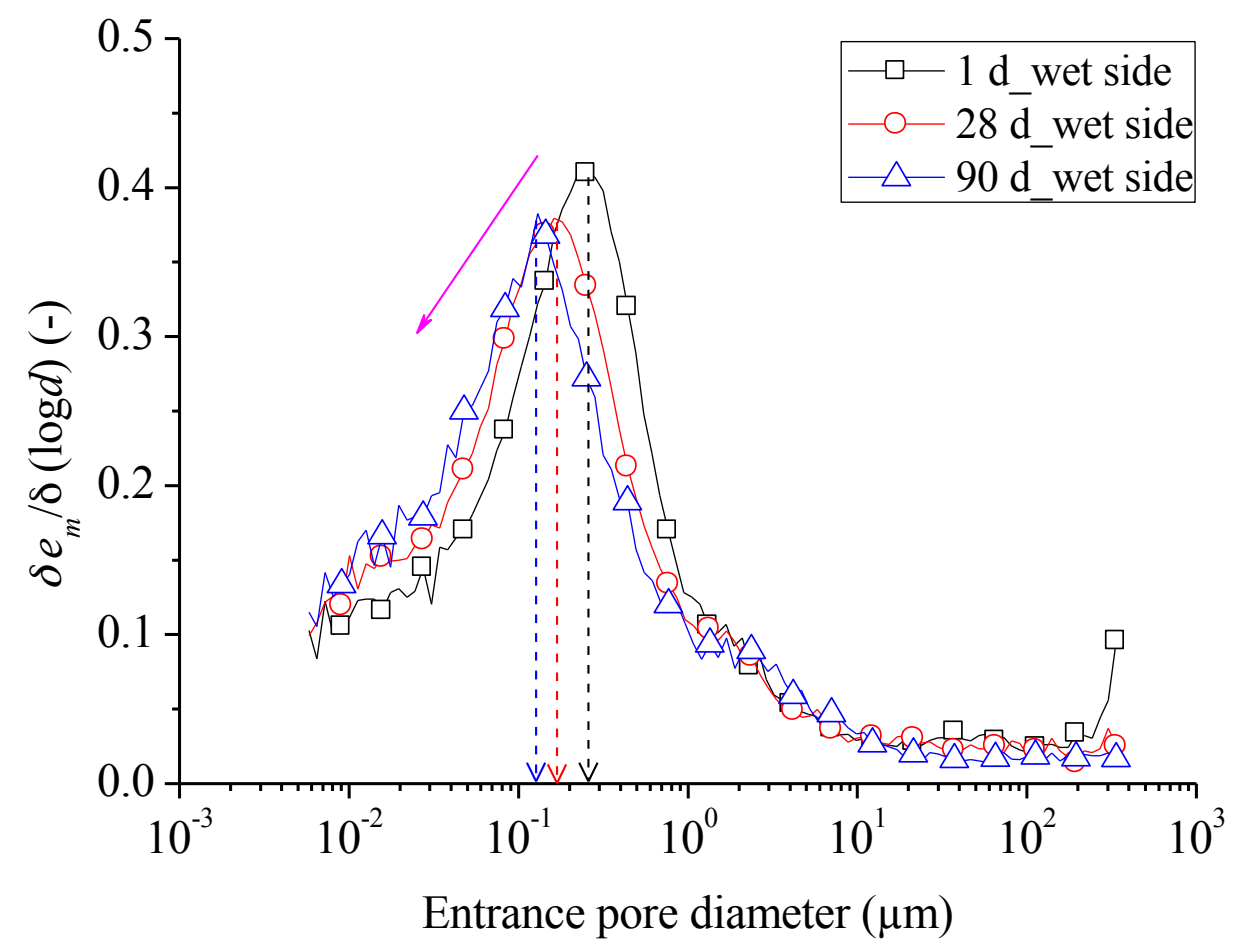

b)

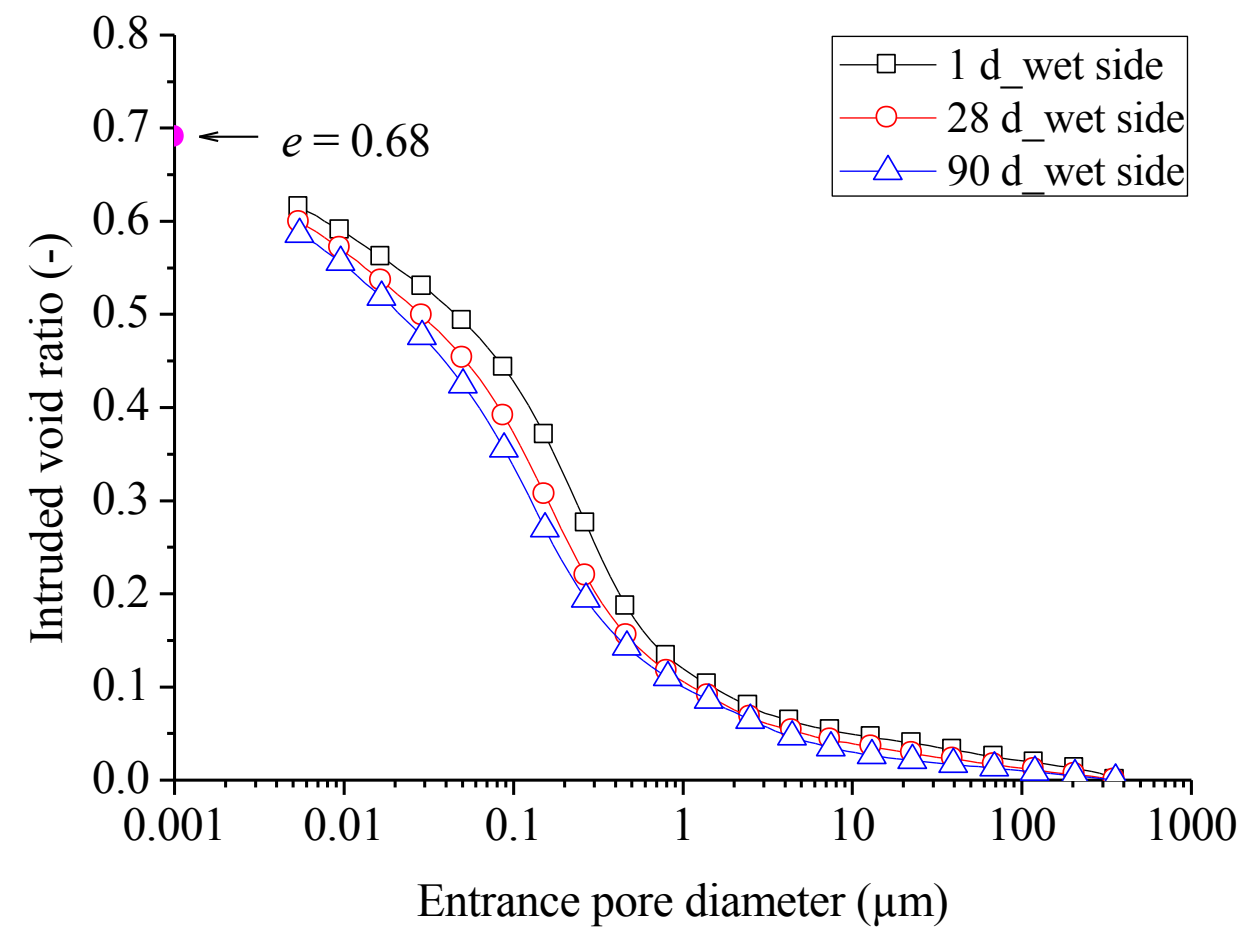

Figure 7 (a) Derived pore size distribution curves of lime-treated sample compacted on the wet side and (b) cumulative curves of lime-treated sample compacted on the wet side 
a)

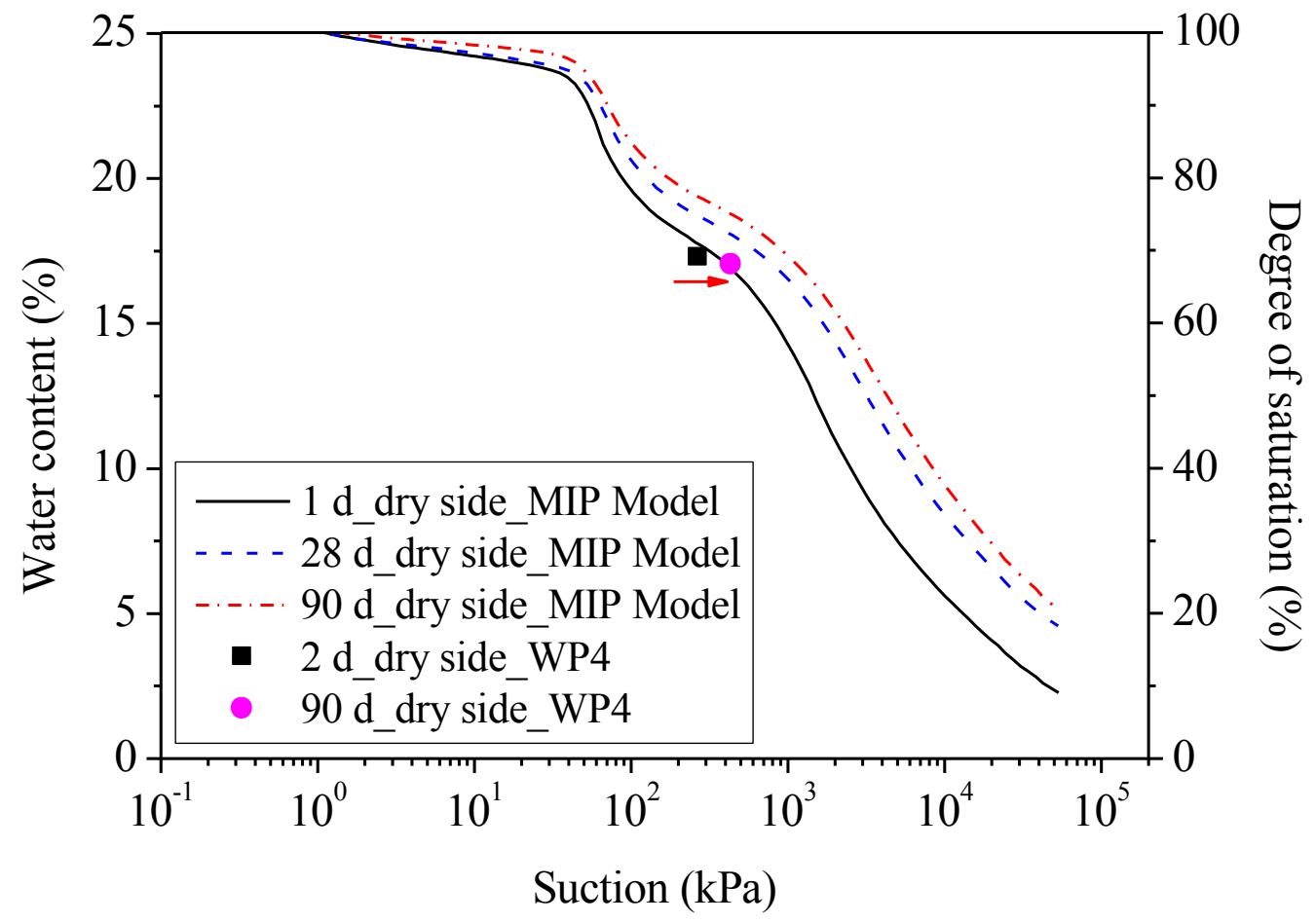

b)

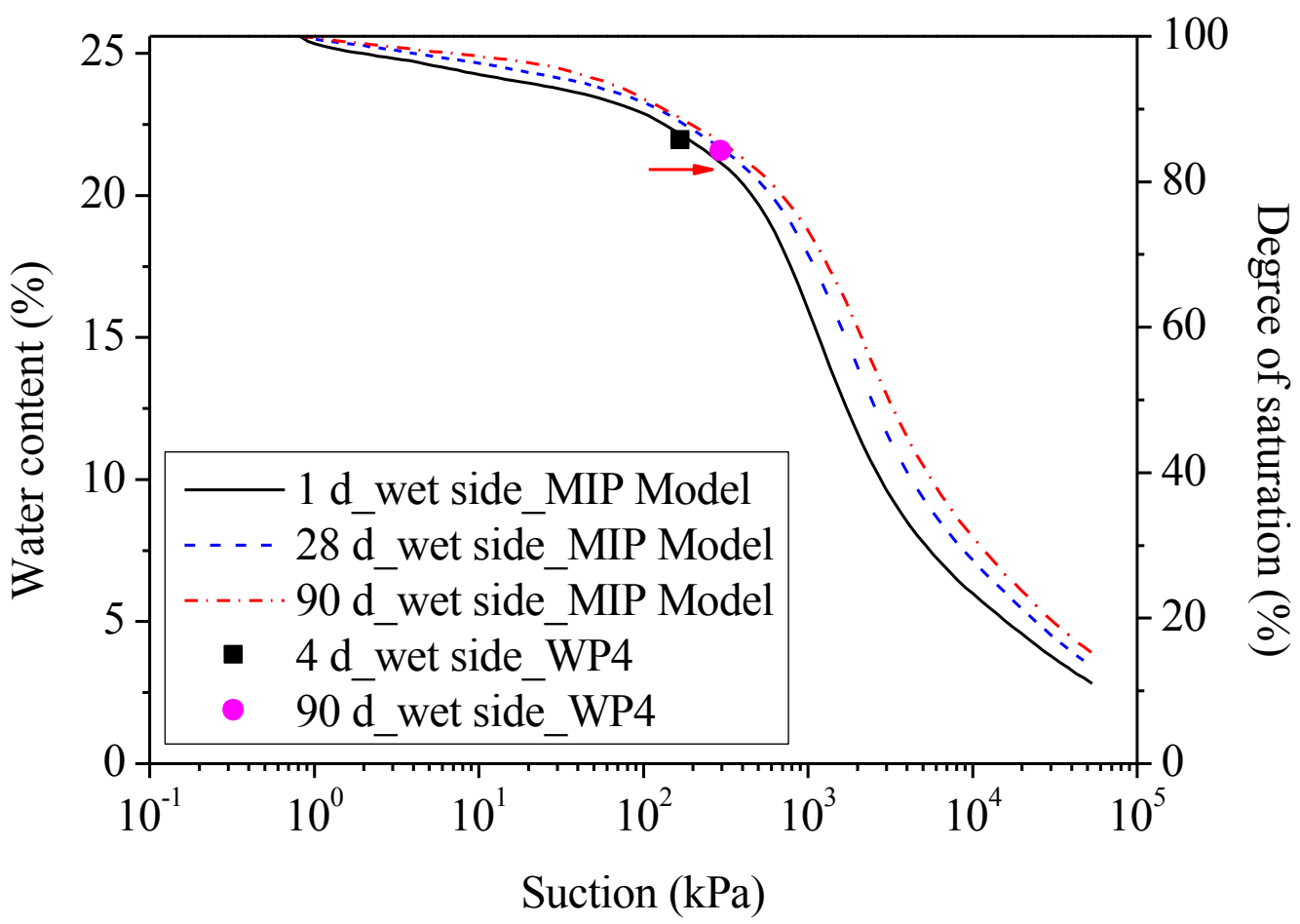

Figure 8 Water retention curves of lime-treated silt determined from MIP data: (a) at dry side; (b) at wet 